\title{
Paleośrodowiskowe znaczenie zmian tempa i charakteru sedymentacji osadów jeziora Jelonek w Borach Tucholskich \\ Paleoenvironmental significance of changes in the rate and type of sedimentation in Lake Jelonek within Poland's Tuchola Pine Forest (Bory Tucholskie)
}

\author{
Mateusz Kramkowski \\ Instytut Geografii i Przestrzennego Zagospodarowania im. S. Leszczyckiego PAN \\ ul. Kopernika 19, 87-100 Toruń \\ mkramkowski@geopan.torun.pl
}

Zarys treści. Jezioro Jelonek położone jest w Polsce północnej w Borach Tucholskich $\left(53^{\circ} 45^{\prime} 58 \mathrm{~N}, 18^{\circ} 23^{\prime} 30 \mathrm{E}\right)$. Zajmuje ono rynnę subglacjalną, bezpośrednio przylegającą do doliny rzeki Wdy. W artykule podjęto problematykę rekonstrukcji środowiska przyrodniczego na podstawie analiz osadów dennych tegoż jeziora, w tym szczególnie tempa sedymentacji i zmienności mikrolitofacjalnej. Z najgłębszej części jeziora pobrano rdzenie osadów, z których złożono pełen profil (JEL14) obejmujący młodszy dryas i holocen. W artykule zaprezentowano analizę zmienności tempa i charakteru sedymentacji w osadach w ciągu prezentowanego okresu. Uzyskane wyniki odniesiono do modelu wiek-głębokość, który powstał na bazie 14 dat radiowęglowych AMS, warwochronologii, kryptotefry Askja 1875 AD oraz korelacji z profilami pyłkowymi. W przeważającej części osady w profilu są rocznie laminowane, jednak w okresie subatlantyckim przez około tysiąc lat (1870-870 cal BP) zarejestrowano zanik laminacji połączony ze znaczącym wzrostem tempa sedymentacji osadu. W osadzie tego okresu widoczne są także liczne przewarstwienia, charakterystyczne dla subakwalnych spływów po stokach misy. Zestawienie wszystkich analiz pozwoliło na połączenie zmian sedymentologicznych z wahaniami poziomu wody w jeziorze oraz próby rekonstrukcji ich uwarunkowań paleośrodowiskowych.

Słowa kluczowe: osady jeziorne, jezioro Jelonek, zmiany sedymentologiczne, wahania poziomów wody, Bory Tucholskie.

Keywords: lake sediments, Poland, Lake Jelonek, sedimentological changes, water-level fluctuations, Tuchola Pine Forest.

\section{Wstęp}

Geneza i ewolucja jezior jest efektem współdziałania procesów endo- i egzogenicznych oraz zmienności klimatu. Procesem zachodzącym nieprzerwanie w cyklu funkcjonowania jezior od początku powstania aż do ich zaniku i przekształcenia w torfowiska jest sedymentacja osadów. Jej charakter i tempo jest zmienne i wynika z wielu czynników, które generalnie można podzielić na dwie grupy: czynniki autochtoniczne i allochtoniczne. Osady autochtoniczne składają się z substancji tworzących się w samym zbiorniku w efekcie wytrącania z wody w procesach biochemicznych i fizycznochemicznych, jak również ze szczątków organizmów (głownie fitoplanktonu) oraz szczątków roślinnych. Osady al- 
lochtoniczne składają się z komponentów dostarczonych do jeziora ze zlewni. W ich skład wchodzą cząstki mineralne, detrytus roślinny, rozpuszczone w wodzie substancje chemiczne. Składniki te dostarczane są wraz z wodami dopływającymi do zbiornika, jak również w ramach nawiewania przez wiatr. W większości jezior umiarkowanej szerokości geograficznej tempo akumulacji uzależnione jest od dwóch czynników. Pierwszym jest erozja w zlewni i strefie brzegowej, która dostarcza zwiększoną ilość materiału i podnosi tempo sedymentacji. Drugim czynnikiem jest produktywność jeziora, związana z jego żyznością. Zwiększona dostawa biogenów powoduje zintensyfikowanie rozwoju fitoplanktonu, co za tym idzie - zwiększoną akumulację ich obumarłych szczątków w osadzie, jak również pośrednio przyczynia się do zwiększenia wytrącania z wody węglanu wapnia. W większości prac paleolimnologicznych tempo akumulacji osadów prezentuje się na krzywej będącej pochodną profilu wiek-głębokość, jak również na krzywej grubości lamin w przypadku osadów laminowanych (Tylmann i inni, 2013; Ott i inni, 2016; Kinder i inni, 2020).

Podczas prac paleogeograficznych na terenie Borów Tucholskich udokumentowano wstępnie kilka jezior z osadami rocznie laminowanymi, wśród nich jezioro Jelonek (Błaszkiewicz, 2005; Filbrandt-Czaja, 2009; Ott i inni, 2016). Duży potencjał paleogeograficzny tych osadów wynikający z rocznej rozdzielczości oraz możliwość zastosowania nowoczesnych technik badawczych, zainspirowały autora do podjęcia szczegółowych analiz, w tym analizy mikrolitofacjalnej.

We wcześniejszych opracowaniach osady jeziora Jelonek analizowane były pod kątem obecności pyłku (Filbrandt-Czaja, 2009), okrzemek (Skulmowska, 2007) i wioślarek (Zawisza, 2008, 2016). Analiza okrzemkowa miała charakter jedynie ekspertyzowy i realizowana była w ramach pracy magisterskiej na Uniwersytecie Mikołaja Kopernika w Toruniu. Została ona wykonana w niewielkiej rozdzielczości z uwzględnieniem ograniczonej liczby taksonów, czego efektem jest ogólny obraz stanu ekologicznego jeziora. Analizy wioślarkowe (Zawisza, 2008; Zawisza i inni, 2016), realizowane były w ramach rozprawy doktorskiej w Instytucie Nauk Geologicznych PAN. Analizy wykonane zostały z rozdzielczością co $10 \mathrm{~cm}$, zbieżną z analizami palinologicznymi (Filbrandt-Czaja, 2009). Poza chronologią palinologiczną badania te uzupełniono o datowania radiowęglowe, jednak ze względu na duże rozbieżności wyników uzyskane daty nie zostały uwzględnione w rekonstrukcjach paleoekologicznych. Uzyskana na podstawie tych analiz sukcesja roślinna jest zbliżona do innych wyników z obszaru wschodnich Borów Tucholskich i odpowiada regionalnym poziomom pyłkowym dla tego obszaru. Ponadto na podstawie analiz palinologicznej i obecności pyłku roślin uznawanych za indykatory gospodarczej aktywności człowieka (np. pyłek zbóż, babki lancetowatej, chabra bławatka) wydzielone zostały cztery fazy osadnicze. Pierwsza w mezolicie i neolicie, druga w okresie brązu i wczesnego żelaza, co odpowiada kulturze łużyckiej. Trzecia faza przypada na okres żelaza i jest wyraźnie zaznaczona w spektrach pyłkowych. Początek ostatniej czwartej fazy związany jest z okresem wczesnego średniowiecza (Filbrandt-Czaja, 2009).

W niniejszym artykule autor prezentuje zmienność tempa i charakteru sedymentacji w jeziorze Jelonek przedstawioną na krzywej tempa sedymentacji (będącej pochodną modelu wiek-głębokość) i jej relacji do mikro- i makroskopowej struktury osadu. Podjęto również próbę odpowiedzi na pytanie: jakie procesy zachodzące w środowisku przyrodniczym zlewni jeziora Jelonek spowodowały tak znaczące zmiany w przebiegu sedymentacji? 


\section{Obszar badań}

Obszar badań stanowi zlewnia bezpośrednia jeziora Jelonek, która według regionalizacji fizycznogeograficznej położona jest w Borach Tucholskich, w podprowincji Pojezierza Południowobałtyckiego (Kondracki, 1994), w obrębie ostatniego zlodowacenia. Obszar ten graniczy z doliną rzeki Wdy. Badany teren zlokalizowany jest na bezpośrednim przedpolu fazy pomorskiej lądolodu górnovistuliańskiego (ryc. 1).

Wiek fazy pomorskiej w nawiązaniu do nowszych datowań przyjmuje się w granicach od 16,2 tys. lat 14C BP (Kozarski, 1995) do 15,2 tys. lat 14C BP (Marks, 2002). Bezpośrednie otoczenie jeziora Jelonek stanowi sandr Wdy, powiązany z odpływem wód roztopowych w trakcie postoju i recesji lądolodu fazy pomorskiej (ryc. 1). W budowie sandru dominują piaski średnio- i drobnoziarniste. Na południe od jeziora rozciąga się niewielkich rozmiarów obszar przemodelowany eolicznie. Po stronie wschodniej sąsiedztwo stanowi dolina rzeki Wdy. Jezioro ulokowane jest w dnie fluwioglacjalnej rynny subglacjalnej (Niewiarowski, 1959) wchodzącej w skład systemu rzeczno-jeziornego rzeki Wdy (Słowiński i inni, 2014; Błaszkiewicz i inni, 2015). Rynna ukierunkowana jest równoleżnikowo z lekkim odchyleniem północny zachód - południowy wschód. W jej dnie pomiędzy jeziorem a doliną Wdy znajduje się sandrowy poziom z osiadania. Głębokość względna rynny przy uwzględnieniu głębokości jeziora (13,8 m) i miąższości osadów dennych (14,2 m) wynosi ponad $30 \mathrm{~m}$ (ryc. 2).

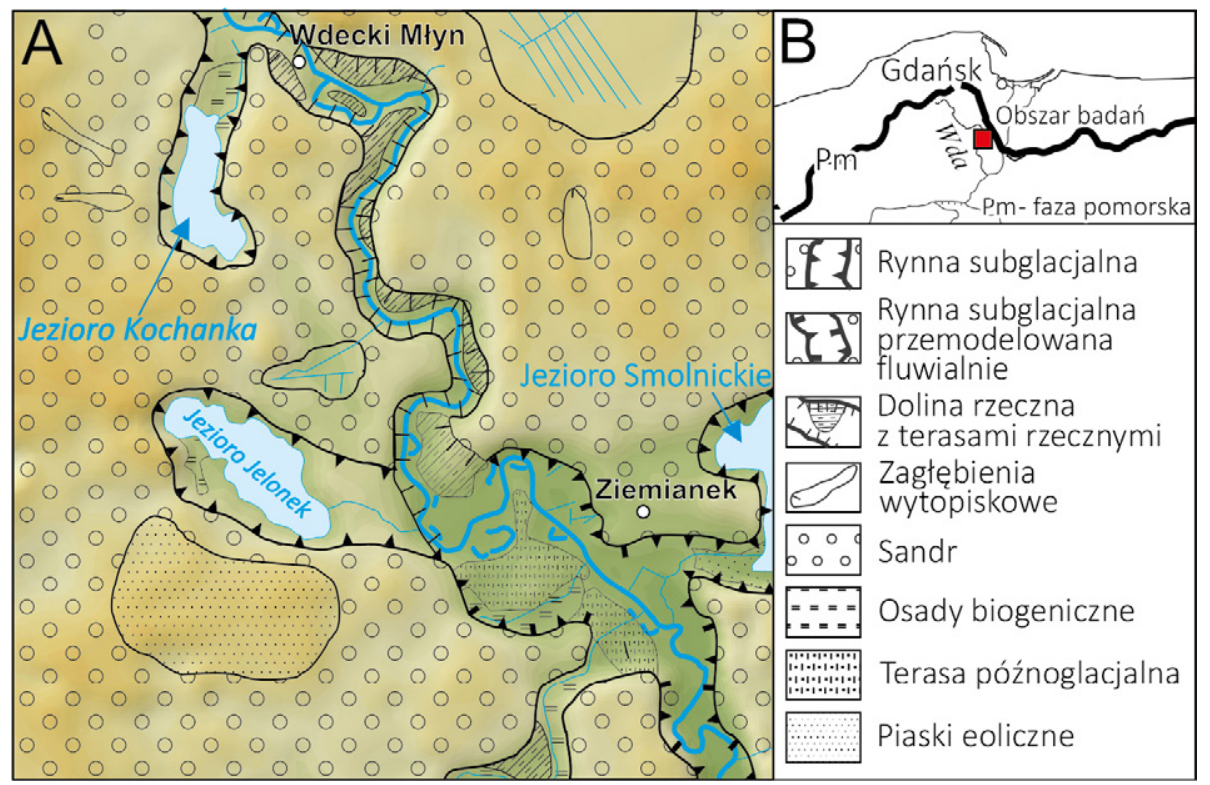

Ryc. 1. Mapa geomorfologiczna otoczenia jeziora Jelonek (A), lokalizacja obszaru badań i granice faz lądolodu górnovistuliańskiego (B)

Geomorphological map of the surroundings of Lake Jelonek (A), location of study site and phases of the Vistulian Glaciation (B)

Źródło: A - Błaszkiewicz i inni (2015), zmienione; B - Kozarski (1975).

Source: A - Błaszkiewicz et al. (2015), modified; B - Kozarski (1975). 


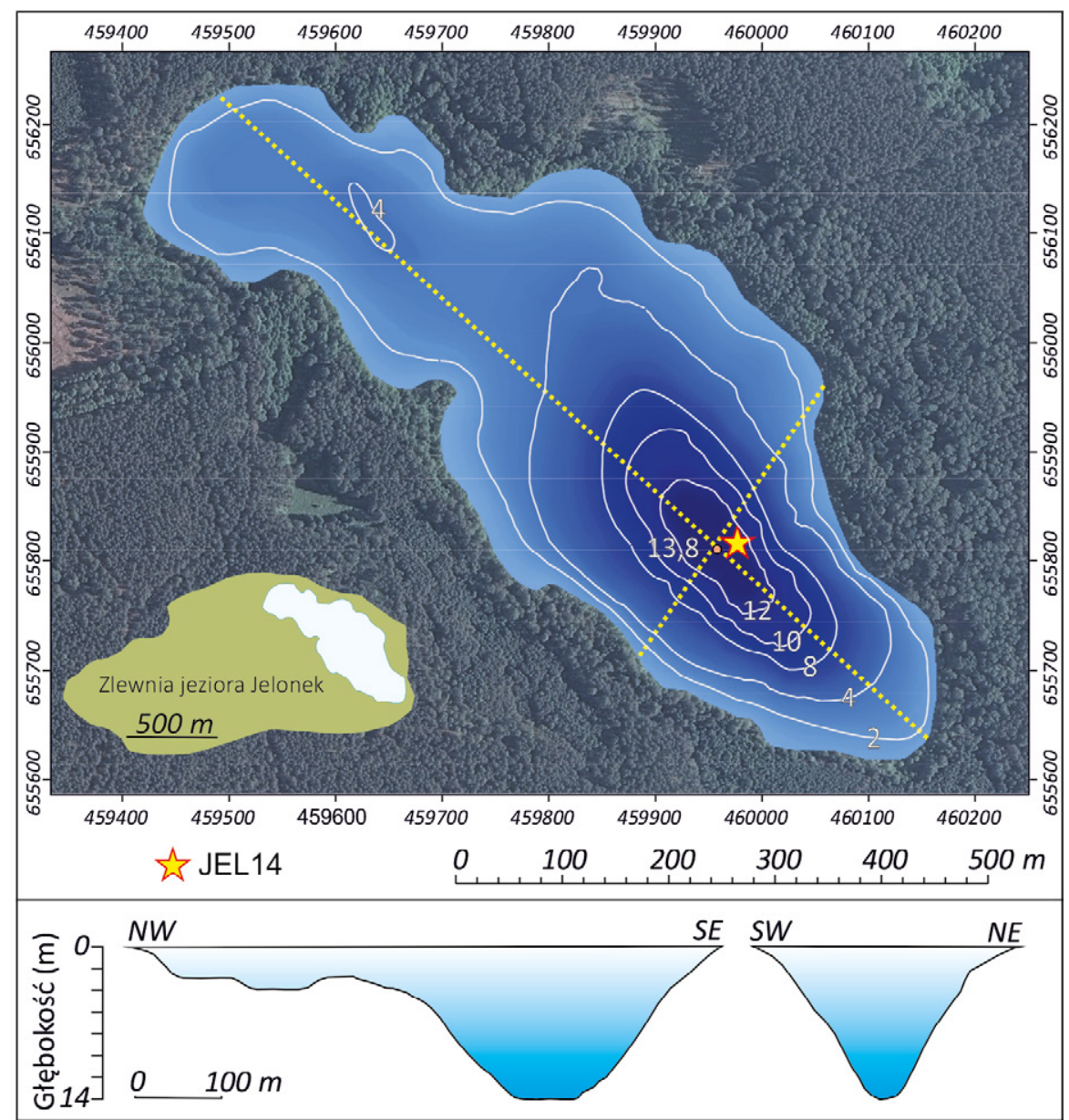

Ryc. 2. Plan batymetryczny, przekrój podłużny i poprzeczny jeziora Jelonek Bathymetric map and transverse profiles of Lake Jelonek

W części północno-wschodniej do jeziora przylega niewielkich rozmiarów terasa jeziorna. Jest ona zbudowana z dobrze wysortowanych piasków drobno- i średnioziarnistych, przemytych. Całość terasy pokryta jest kilkunastocentymetrowej miąższości warstwą murszu i silnie rozłożonego torfu. Południowo-zachodni brzeg jeziora pokrywa się bezpośrednio z krawędzią rynny subglacjalnej. W północnej jego części znajduje się niewielkich rozmiarów zatoka, całkowicie wypełniona osadami jeziornymi i torfem o łącznej miąższości $6 \mathrm{~m}$. W odległości $600 \mathrm{~m}$ na północ od jeziora Jelonek znajduje się jezioro Kochanka.

Zlewnia bezpośrednia jeziora Jelonek zajmuje powierzchnię 111,6 ha i ma ona charakter śródleśny. Jezioro ulokowane jest w północno-wschodniej części zlewni tuż przy dziale wodnym oddzielającym jego zlewnię od zlewni bezpośredniej rzeki Wdy (ryc. 2). Jezioro Jelonek jest jeziorem odpływowym poprzez sztuczny kanał łączący je z rzeką Wdą. Lustro wody jeziora ulokowane jest na wysokości 90,6 m n.p.m. 


\section{Metody}

W ramach prac terenowych w latach 2013-2014 wydobyto z najgłębszej części jeziora przy użyciu próbników UWITEC pełen profil osadów jeziornych o długości $1423 \mathrm{~cm}$.

W ramach prac laboratoryjnych wypreparowanych zostało 17 próbek makroszczątków roślinnych do datowań radiowęglowych. Przygotowano zestaw 218 cienkich szlifów w całości pokrywających profil JEL14 oraz wypreparowano próbki do analiz tefrochronologicznych.

Model wiek-głębokość powstał na bazie: a) warwochronologii, b) datowania radiowęglowego AMS $14 \mathrm{C}$ i c) tefrochronologii.

a) Warwochronologia - szczegółowe analizy mikrolitofacjalne przeprowadzone były przy użyciu mikroskopu petrograficznego Zeiss - JenaPol, w powiększeniu od 32 do 100 razy. W celu określenia wiarygodności chronologii, warwy zliczane były dwukrotnie.

b) Datowanie radiowęglowe AMS 14C - do określenia wieku metodą radiowęglową posłużyło 17 makroszczątków roślin terestrycznych (9 - liście drzew, 8 - młoda kora sosny). Datowania wykonano w Poznańskim Laboratorium Radiowęglowym. Uzyskane daty zostały wykalibrowane przy pomocy aplikacji OxCal v. 4.2 (Reimer i inni, 2009; Reimer i inni, 2013).

c) Tefrochronologia - na podstawie wstępnej warwochronologii bazującej na datach radiowęglowych do analiz wytypowano kilka fragmentów osadu. Każda próbka poddana została obróbce chemicznej. Mikroskopowo separowane były pojedyncze szkliwa wulkaniczne. Następnie przy pomocy sondy JEOL JXA 8230 Electron Probe Microanalyzer określono skład chemiczny szkliwa wulkanicznego, co było podstawą do przyporządkowania analizowanej tefry poszczególnym erupcjom wulkanicznym (Wulf i inni, 2016).

Powstały model wiek-głębokość został przekształcony w krzywą tempa sedymentacji. W artykule poza datami posłużono się podziałem zaproponowanym przez J. Mangeruda i innych (1974), za daty graniczne jednostek holocenu przyjmując lata kalibrowane BP zaproponowane przez A. Walanusa i D. Nalepkę (2010).

\section{Wyniki}

\section{Model wiek-głębokość, krzywa tempa sedymentacji}

Trzy daty uznano za niezgodne chronologicznie - zbyt stare (najprawdopodobniej próbki zawierały materiał redeponowany). Zatem do budowy profilu wiek-głębokość posłużono się 14 datami (ryc. 3). Ze względu na brak materiału mogącego służyć do datowania osadu początek sedymentacji określono na podstawie badań przeprowadzonych przez A. Filbrandt-Czaję (2009). Cytowana autorka na podstawie analiz palinologicznych stwierdziła, że sedymentacja jeziorna rozpoczęła się w okresie młodszego dryasu. Warwochronologia odcinka stropowego zawiera się w przedziale $795 \pm 13$ lat warwowych oraz dla odcinka spągowego wynosi $8620 \pm 184$ lat warwowych. Wyniki datowań radiowęglowych zawierały

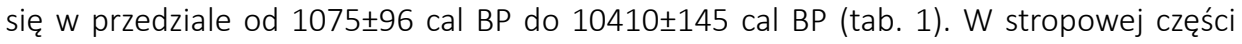
do konstrukcji chronologii użyto także tefry Askja 1875. 
Tabela 1. Zestawienie dat radiowęglowych AMS 14C dates

\begin{tabular}{|l|c|c|c|l|}
\hline Numer & Głębokość $(\mathrm{cm})$ & Wiek C14 & Wiek cal BP & Datowany materiał \\
\hline POZ-70981 & 283 & $1140 \pm 30$ & 1075 & Liść \\
POZ-75414 & 315 & $1200 \pm 30$ & 1123 & Kora sosny \\
POZ-75413 & 336 & $1540 \pm 30$ & 1445 & Kora sosny \\
POZ-75412 & 360 & $1485 \pm 30$ & 1360 & Kora sosny \\
POZ-75411 & 419 & $1635 \pm 30$ & 1413 & Kora sosny \\
POZ-75407 & 488 & $1860 \pm 30$ & 1795 & Kora sosny \\
POZ-75408 & 515 & $1695 \pm 30$ & 1624 & Kora sosny \\
POZ-70980 & 541 & $1770 \pm 30$ & 1649 & Liść \\
POZ-75410 & 592 & $2080 \pm 50$ & 2045 & Liść \\
POZ-70971 & 793 & $1975 \pm 30$ & 1935 & Liść \\
POZ-70972 & 985 & $3120 \pm 35$ & 3340 & Liść, nasiona brzozy \\
POZ-70975 & 1012 & $3510 \pm 35$ & 3764 & Liść \\
POZ-70974 & 1128 & $5405 \pm 35$ & 6163 & Liść \\
POZ-70976 & 1154 & $5840 \pm 35$ & 6645 & Liść \\
POZ-70977 & 1222 & $7810 \pm 50$ & 8690 & Liść \\
POZ-70978 & 1237 & $9260 \pm 50 \pm 50$ & 10410 & Kora sosny \\
POZ-70979 & 1270 & Kora sosny \\
\hline
\end{tabular}

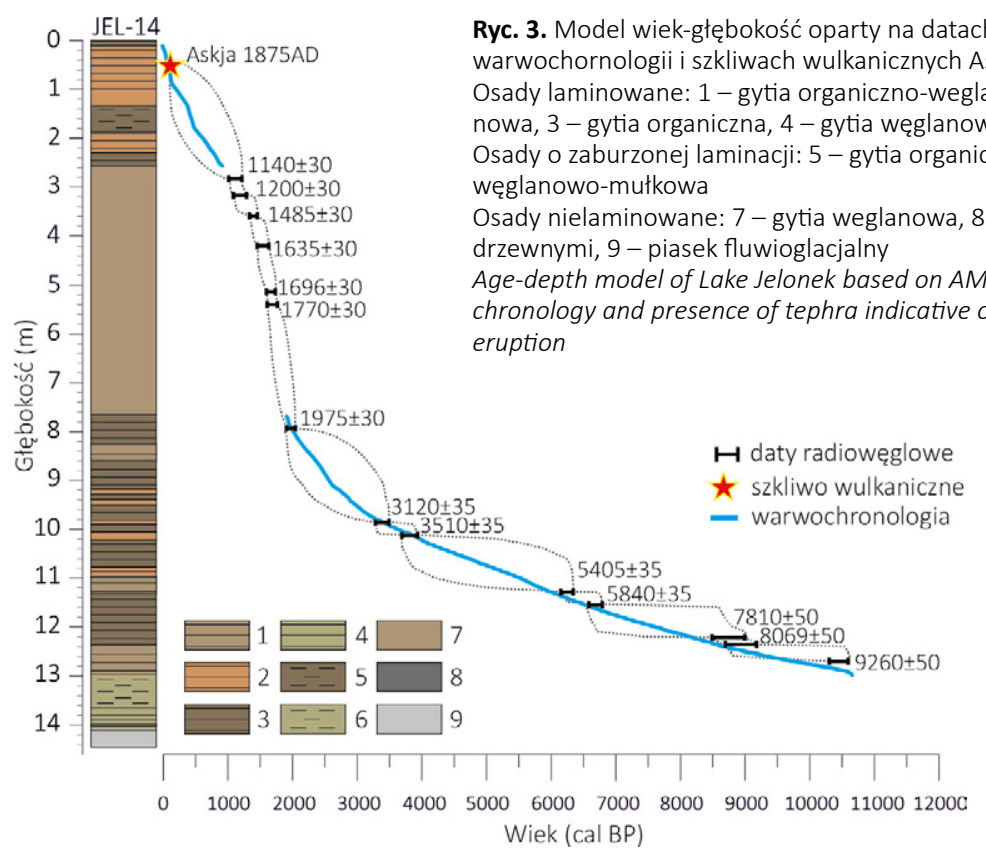




\section{Tempo i charakter sedymentacji}

W młodszym dryasie, ze względu na brak wiarygodnych datowań, niemożliwe było określenie tempa sedymentacji. Akumulowany w tym okresie osad jest homogeniczny. Składa się on w przeważającej części z drobnego materiału mineralnego z dużym udziałem terygenicznego węglanu wapnia oraz z niewielkimi domieszkami pancerzyków okrzemek i ziaren węglanu autogenicznego. Ilość węglanów i okrzemek w obrazie mikroskopowym wzrasta ku stropowi.

Dopiero w połowie okresu preborelanego (10610 \pm 184 cal BP) widoczne jest przejście z osadów homogenicznych do laminowanych. Przez pierwsze 25 lat odkładania osadów laminowanych tempo ich sedymentacji wynosiło ok. 1,5 mm/rok i związane było ze znaczącym udziałem ziaren mineralnych w składzie osadu. Po tym czasie tempo do końca okresu preborealnego wynosiło średnio 0,32 mm/rok. W analizie mikroskopowej cienkich płytek widoczne jest, że główną składową osadu laminowanego stanowi amorficzna materia organiczna z dużym udziałem detrytusu roślinnego, cysty złotowiciowców oraz niewielka ilość kalcytu, którego kryształy są bardzo małych rozmiarów.

Przejście do okresu borealnego (10150 cal BP) nie zaznacza się w makro- i mikroskopowym obrazie osadu. W okresie tym spada jedynie średnie tempo sedymentacji, które wynosi $0,25 \mathrm{~mm} /$ rok. Sedymentacja ma wyrównany przebieg i jej tempo w całym okresie borealnym mieści się w przedziale 0,13-0,64 mm/rok.

Kolejna granica między okresami borealnym a atlantyckim (8950 cal BP) również nie zaznacza się w zmianie typu osadu. Zmiana sedymentologiczna widoczna jest dopiero po ok. 700 latach trwania okresu atlantyckiego. W osadzie całkowicie zanika kalcyt, a osad charakteryzuje się dużą zawartością amorficznej materii organicznej i bardzo drobnego detrytusu roślinnego. Udział okrzemek jest niewielki, a na sezonowość sedymentacji wskazują jedynie cysty złotowiciowców. Formy przetrwalnikowe tych glonów (cysty) mogą być odkładane zarówno późną jesienią, jak i wczesną wiosną (Hernández-Almeida i inni, 2014), stąd też ich warstwy ukazują granicę między poszczególnymi latami. Wraz ze zmianą typu osadu wzrasta tempo sedymentacji i jej przebieg jest mniej wyrównany. Zmienność z roku na rok zwiększa się do zakresu 0,2-1,5 mm/rok, co dla całego okresu atlantyckiego daje średnie tempo sedymentacji 0,41 mm/rok.

W okresie subborealnym (5750 cal BP do 2550 cal BP) notowany jest dalszy wzrost tempa sedymentacji. Do ok. 3000 cal BP średnia wzrasta dość równomiernie do 0,57 mm/rok przy jeszcze większym zróżnicowaniu (0,15-2,7 mm/rok). Natomiast w ostatnich 450 latach okresu subborealnego średnie tempo wzrasta prawie dwukrotnie do 1,1 mm/rok, przy maksymalnych wartościach 3,7 mm/rok. W okresie tym widoczne są także zmiany w charakterze sedymentacji. Notuje się pięć przewarstwień z laminacją węglanową. W ich obrębie lamina jasna składa się praktycznie tylko z węglanu wapnia. Warstwa ciemna składa się z amorficznej materii organicznej, pojedynczego drobnego detrytusu roślinnego, kryształów pirytu i pojedynczych ziaren mineralnych, a także z pojedynczych okryw okrzemek. Pomiędzy przewarstwieniami z laminacją węglanową ponownie znika kalcyt, w osadzie przeważa materia organiczna, detrytus roślinny, kryształy pirytu, a wyznaczenie sezonowości możliwe jest jedynie na podstawie obecności cyst złotowiciowców. Osad ma charakter zbliżony do akumulowanego w okresie atlantyckim. Ostatnie przewarstwienie z laminacją węglanową kończy okres subborealny.

Okres subatlantycki jest najbardziej zróżnicowany pod względem tempa sedymentacji w historii funkcjonowania jeziora Jelonek. Po ponownym zaniku węglanu wapnia w osa- 


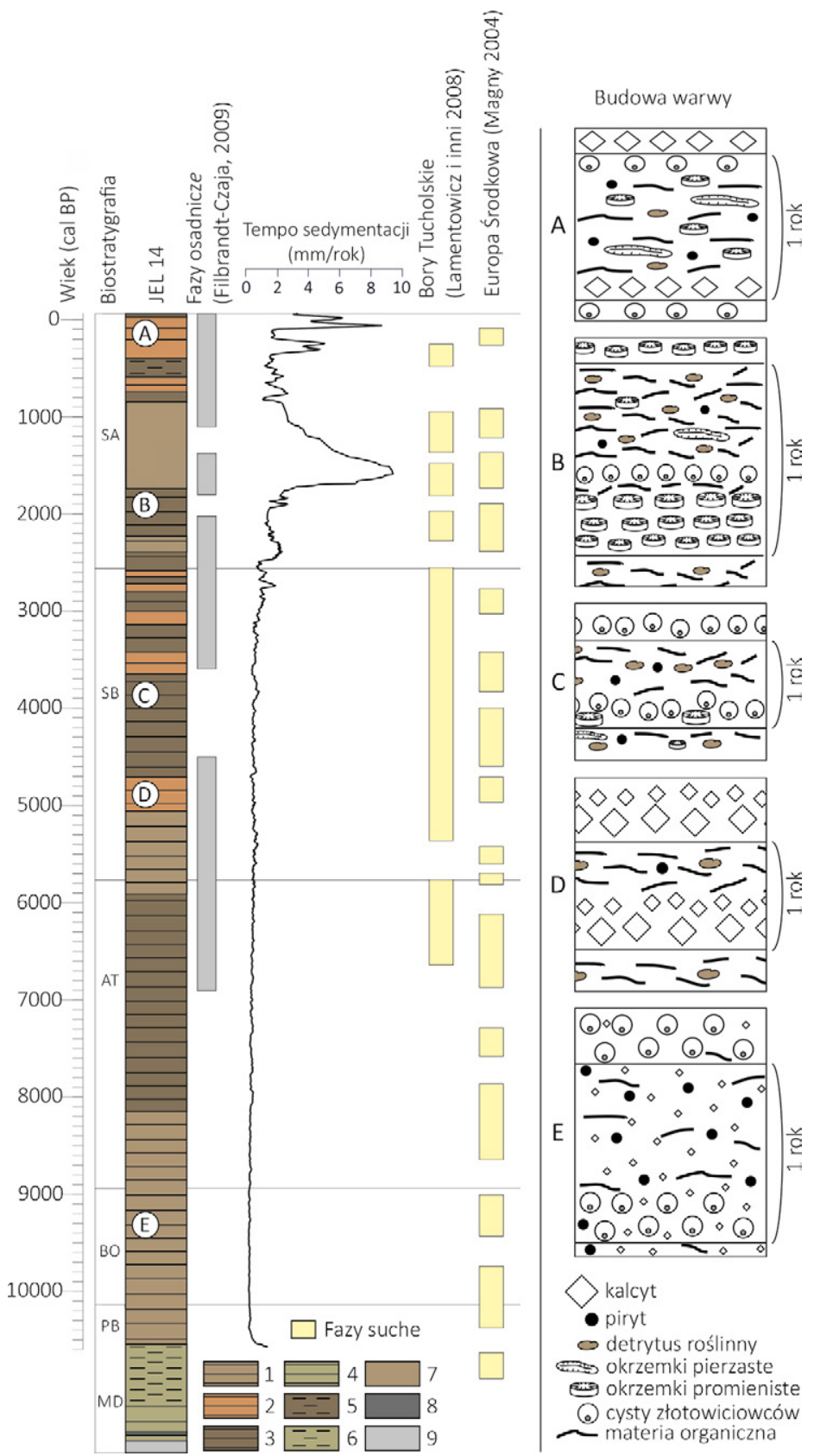

Ryc. 4. Krzywa tempa sedymentacji wraz z profilem osadów, fazami osadniczymi i fazami obniżonego poziomu wody w jeziorach

Osady laminowane: 1 - gytia organiczno-weglanowa, 2 - gytia węglanowa, 3 - gytia organiczna, 4 - gytia węglanowo-mułkowa

Osady o zaburzonej laminacji: 5 - gytia organiczna, 6 - gytia węglanowo-mułkowa

Osady nielaminowane: 7 - gytia weglanowa, 8 - piasek z weglami drzewnymi, 9 - piasek fluwioglacjalny Curve for sedimentation rate with composite profile, phases of human settlement and low-water phases 
dzie sedymentacja rozpoczyna się gytią organiczno-okrzemkową z wyraźnie wykształconą sezonowością zaznaczającą się w postaci warstw okrzemek promienistych. Pozostałą część osadu stanowi wymieszana materia organiczna, drobny detrytus roślinny, pojedyncze okrzemki pierzaste i promieniste, a także pancerzyki orzęsek i piryt framboidalny. Średnie tempo sedymentacji dla tego fragmentu rdzenia wynosi $2,2 \mathrm{~mm} /$ rok.

Około roku 1870 cal BP dochodzi do kolejnej gwałtownej zmiany, wyróżniającej się zanikiem laminacji, który utrzymuje się do ok. 870 cal BP. Osady akumulowane w ciągu tego tysiącletniego okresu zajmują w profilu 5,1 m, przy średnim tempie sedymentacji na poziomie 7,7 mm/rok, a wartości maksymalnej 15,3 mm/rok. W zapisie sedymentologicznym w początkowej fazie przeważa osad organiczny z dużym udziałem okrzemek, licznym detrytusem roślinnym oraz niewielką ilością kryształów kalcytu. Wraz z przebiegiem sedymentacji w osadzie widoczny jest stopniowy wzrost udziału kalcytu, który swoje maksimum osiąga ok. 1550 cal BP, kiedy to staje się przeważającym komponentem w osadzie. Pozostałe składniki, takie jak materia organiczna i okrzemki, w obrazie mikroskopowym stanowią tylko niewielką domieszkę. Następnie na przestrzeni kolejnych 200 lat przebieg sedymentacji zmienia się i osad staje się bardziej organiczny. Po tym czasie między 1300 a 870 cal BP w osadzie ponownie dominują węglany, a po 870 cal BP powraca laminacja.

W obrębie nielaminowanego fragmentu rdzenia widocznych jest ponad 60 drobnych przewarstwień materiału jaśniejszego o strukturze charakterystycznej dla form spływowych (ryc. 5). Generalnie spąg każdego z tych przewarstwień ma charakter powierzchni erozyjnej, wyraźnie odróżniającej się od poniżej leżących osadów. Z kolei górna część jest nieregularna, z widocznymi strukturami fluidalnymi, charakterystycznymi dla uwodnionego materiału górnej części spływu. Analiza mikrolitofacjalna wskazuje, że materiał spływowy zawiera większą ilość kryształów kalcytu, w postaci często zagregowanej, wskazującej na redepozycję tego materiału z płytszej, litoralnej części jeziora.

Od 870 cal BP do roku 2008 ponownie występuje laminacja, z widoczną również dużą zmiennością sedymentologiczną. Naprzemiennie występują osady węglanowe i organiczne z dużym udziałem okrzemek. Tempo sedymentacji również wykazuje dużą zmienność. Do 320 cal BP średnie tempo wynosi 2,3 mm/rok. Po tym okresie znacząco wzrasta, a w ostatnich latach wynosi $3,9 \mathrm{~mm} /$ rok.
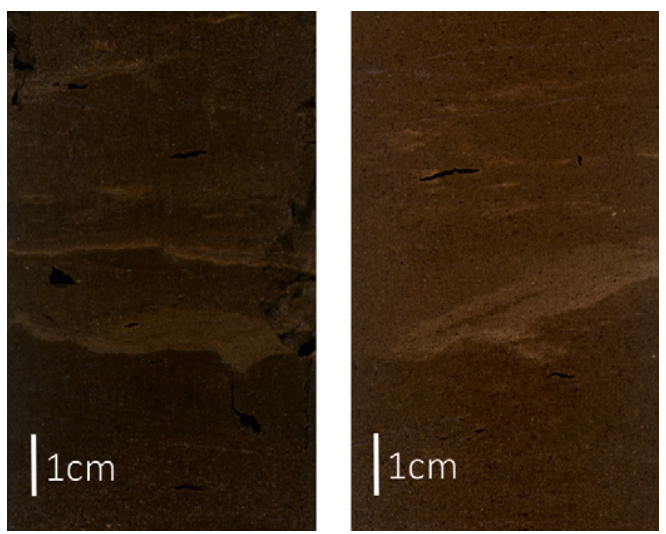

Ryc. 5. Przykłady form spływowych w osadach subatlantyckich Examples of underwater flow in subatlantic sediments 


\section{Dyskusja}

Sedymentacja od początku istnienia jeziora do ok. 2000 cal BP ma przebieg nieodbiegający od innych jezior północnej Polski (Ralska-Jasiewiczowa, 1998; Tylmann i inni, 2013; Kinder i inni, 2020). Relatywnie wysokie tempo sedymentacji i duża dostawa materiału klastycznego w młodszym dryasie odzwierciedla małą stabilność środowiska w tym okresie. Ochłodzenie, a w konsekwencji rozluźnienie szaty roślinnej spowodowało rozwój procesów eolicznych i denudacyjnych (Starkel, 1977; Błaszkiewicz i inni, 2005; Kaiser i inni, 2009). Jest to sytuacja powszechnie stwierdzana w tym okresie na terenie całej Europy (Błaszkiewicz, 2005; Latałowa i Borówka, 2006; Väliranta i inni, 2006; Apolinarska i Hammarlund, 2009; Apolinarska i inni, 2012). Wzrost średniej temperatury powietrza na początku holocenu (wzrost średniej temperatury rocznej początku holocenu określany jest na ok. $5^{\circ} \mathrm{C}$; Ralska-Jasiewiczowa, 1998) spowodował rozwój szaty roślinnej, migrację na te tereny drzew liściastych i rozwój lasów iglasto-liściastych oraz poprawę jakości gleb. W jeziorze nastąpiło polepszenie warunków edaficznych, rozwój fitoplanktonu i doszło do stabilizacji sedymentacji. Od tego momentu tempo sedymentacji kształtowane było głównie przez trofię i produktywność jeziora. Procesy te od okresu atlantyckiego dodatkowo modyfikowane były poprzez działalność człowieka, która przejawiała się w zmianach zagospodarowania zlewni (odlesienia, wypalenia, działalność rolnicza), jednak wpływ ten nie ma cech gwałtownych, ekstremalnych zdarzeń.

Na szczególną uwagę natomiast zasługuje wzrost tempa sedymentacji udokumentowany w środkowej części okresu subatlantyckiego. Tak duże tempo sedymentacji jest bardzo nietypowe dla jezior tego regionu. Podobną sytuację, lecz ze znacznie mniejszym tempem sedymentacji na podstawie profili palinologicznych jezior Suszek i Kęsowo, sygnalizuje jedynie G. Miotk-Szpiganowicz (1992). Autor uważa, że za tak duże tempo sedymentacji odpowiada zwiększenie żyzności zbiornika i większa produkcja pierwotna oraz odkładanie osadów redeponowanych z płytszych stref zbiornika. Wskazuje na to ponad 60 przewarstwień o charakterze spływów, zawierających więcej węglanu wapnia niż osad autochtoniczny (ryc. 5). Tego typu interpretację potwierdzają pośrednio uzyskane daty radiowęglowe. Wiek makroszczątków pochodzących z tego fragmentu rdzenia okazał się zbyt stary i nie został uwzględniony w chronologii. Spowodowane to zostało domieszką starszych osadów, które wraz z makroszczątkami zostały w wyniku resuspensji i spływów przetransportowane ze strefy litoralnej do głęboczka. W tym przypadku na redepozycję osadów mogło mieć wpływ kilka czynników. Głównym było zapewne obniżenie poziomu wody, co spowodowało przesunięcie granicy zasięgu mieszania osadów w głąb jeziora.

Na znaczące obniżenie poziomu wody w tym okresie wskazuje także przewarstwienie osadów organicznych na stanowisku nieopodal jeziora Kochanka (ok. 1 km na północ od jeziora Jelonek). Osad ten znajduje się $4 \mathrm{~m}$ poniżej aktualnego poziomu powierzchni terenu, jego data radiowęglowa wskazuje 1945 cal BP (Błaszkiewicz i inni, 2015). Ponadto na niższy poziom wody w tym czasie w Borach Tucholskich wskazują M. Lamentowicz i inni, (2006). Także M. Magny (2004) wskazuje na obniżenie w połowie okresu subatlantyckiego poziomu wody jezior w Europie Środkowej (ryc. 4).

Ponadto na intensywność mieszania mogło mieć wpływ odlesienie (Filbrandt-Czaja, 2009), przyczyniające się do silniejszego oddziaływania wiatru na powierzchnię jeziora, a w efekcie do głębszego zasięgu miksji (Kinder i inni, 2020). Trzecim z kolei czynnikiem mogło być zmniejszenie się wysokości słupa wody (relatywnej głębokości zbiornika) wy- 
nikające z przyrastania na dnie osadu. Od początku istnienia jeziora do schyłku okresu subborealnego w wyniku wypełniania osadami poziom dna podniósł się o ponad $6 \mathrm{~m}$.

Zakładając, że jednymi z czynników warunkujących zachowanie laminacji są warunki beztlenowe i brak ruchów wody, podobne uwarunkowania środowiskowe mogły być związane z zanikiem laminacji w tym czasie. Należy stwierdzić, że w wyniku wspomnianych powyżej procesów cała kolumna wody była natleniona, na co wskazuje zanik pirytu, a przy dnie dochodziło do ruchów masowych, w efekcie których nastąpiła intensywna redepozycja osadów. To powodowało zwiększoną bioturbację oraz mieszanie osadów przydennych i nie pozwalało zachować się laminacji.

Również analiza diatomologiczna i wioślarkowa (Skulmowska, 2007; Zawisza, 2008, 2016) oraz zwiększona ilość pancerzyków orzęsek wskazują na wyraźny wzrost eutrofizacji w tym okresie. Wzrost ten mógł być efektem ługowania związków ze zlewni użytkowanej rolniczo i dostawania się ich do wód gruntowych i jeziora (Bajkiewicz-Grabowska, 2002).

Jednocześnie należy zwrócić uwagę, że maksimum ilości kalcytu w osadzie i najwyższe tempo sedymentacji łączy się czasowo z trzecią fazą osadniczą (ok. 1800-1400 cal BP). Po tym czasie pogarszają się warunki bytowania człowieka, przychodzi ochłodzenie i wzrost wilgotności klimatu. Zmusza to ludność do migracji, rozpoczyna się okres nazywany wędrówką ludów. Zlewnia jeziora Jelonek po opuszczeniu przez ludzi zaczyna się regenerować. Widoczne jest to we wzroście ilości drzew, w tym szczególnie graba, który zajmuje szybko obszary rolne porzucone przez człowieka (Filbrandt-Czaja, 2009). Dochodzi do wzrostu poziomu wody w zbiorniku, osad staje się bardziej organiczny. Może to wynikać z zalania roślinności przybrzeżnej, większej dostawy materii organicznej i detrytusu. Jednocześnie podniesienie się słupa wody i wzrost drzew ogranicza resuspensję i materiał ma charakter bardziej autochtoniczny. Powoduje to, że ok. 1080 r. (870 cal BP) rozpoczęła się ponowna sedymentacja osadów laminowanych, a tempo sedymentacji znacznie się obniżyło.

\section{Wnioski}

Całość przeprowadzonych analiz osadów dennych jeziora Jelonek pozwoliła na udokumentowanie dużej zmienności tempa i charakteru sedymentacji. Zwykle w niezaburzonym ekstremalnymi zdarzeniami cyklu funkcjonowania jeziora sedymentacja trwa na wyrównanym poziomie, wynikającym z produkcji pierwotnej. W przypadku jeziora Jelonek okazało się, że zapisane w osadach zmiany tempa i charakteru sedymentacji znacząco odbiegają od znanych polskich i europejskich stanowisk. Jest ona szczególnie widoczna w okresie subatlantyckim, kiedy to średnie tempo sedymentacji wynosiło 7,7 mm/rok, czyli było o 5,5 mm/rok wyższe niż w okresie poprzedzającym. Jednocześnie w akumulowanych ówcześnie osadach całkowicie zanika laminacja, pojawiły się liczne przewarstwienia materiału redeponowanego. Zaobserwowane zmiany w sedymentacji pozwalają wnioskować, że głównym ich powodem były zmiany poziomu wody w jeziorze. Podczas obniżania się poziomu wody dochodziło do kształtowania się nowej strefy litoralnej, co skutkowało redepozycją odłożonych w strefie litoralnej osadów. Ponadto zmniejszenie wysokości słupa wody powodowało zmiany w głębokości miksji i natlenienia strefy przydennej. Nakładanie się tych czynników przyczyniło się do zaniku laminacji i zwiększonej sedymentacji osadów węglanowych. Ponowne podniesienie się poziomu wody oraz powiązane z tym zalewanie 
strefy przybrzeżnej wraz z roślinnością powodowało zwiększoną dostawę materii organicznej i sedymentację osadów bardziej organicznych. Skutkowało to równocześnie pogarszaniem warunków tlenowych i płytszą miksją, co z kolei prowadziło do zachowania się na dnie laminacji. Mała skala jeziora i zlewni oraz jej pozycja w relacji do doliny Wdy powoduje, iż procesy depozycji osadów w jeziorze Jelonek są powiązane ze zmianami klimatycznymi oraz przemianami w zlewni wywołanymi działalnością człowieka. Stąd też jest to wyjątkowy obiekt do prowadzenia rekonstrukcji peleośrodowiskowych na tle globalnych zmian klimatu w holocenie oraz narastającej antropopresji.

Ryciny i tabele, pod którymi nie zamieszczono źródła, są opracowaniami własnymi autora artykułu.

Praca powstała w wyniku realizacji projektu badawczego o nr UMO-2015/19/N/ ST10/02655 finansowanego ze środków Narodowego Centrum Nauki.

\section{Piśmiennictwo}

Apolinarska K., Hammarlund D., 2009, Multi-component stable isotope records from Late Weichselian and early Holocene lake sediments at Imiotki, Poland: palaeoclimatic and methodological implications, Journal of Quaternary Science, 24, s. 948-959. https://doi.org/10.1002/jqs.1274.

Apolinarska K., Woszczyk M., Obremska M., 2012, Late Weichselian and Holocene palaeoenvironmental changes in northern Poland based on the Lake Skrzynka record, Boreas, 41, s. 292-307. https://doi.org/10.1111/j.1502-3885.2011.00235.x.

Bajkiewicz-Grabowska E., 2002, Obieg materii w systemach rzeczno-jeziornych, Wydawnictwo Uniwersytetu Warszawskiego, Warszawa.

Błaszkiewicz M., 2005, Późnoglacjalna i wczesnoholoceńska ewolucja obniżeń jeziornych na Pojezierzu Kociewskim (wschodnia część Pomorza), Prace Geograficzne, 201, IGiPZ PAN, Warszawa.

Błaszkiewicz M., Piotrowski J.A., Brauer A., Gierszewski P., Kordowski J., Kramkowski J., Lamparski P., Lorenz S., Noryśkiewicz A.M., Ott F., Słowiński M., Tyszkowski S., 2015, Climatic and morphological controls on diachronous postglacial lake and river valley evolution in the area of Last Glaciation, northern Poland, Quaternary Science Reviews, 109, s. 13-27. https://doi.org/10.1016/j. quascirev.2014.11.023.

Filbrandt-Czaja A., 2009, Studia nad historiq szaty roślinnej i krajobrazu Borów Tucholskich, Wydawnictwo Naukowe Uniwersytetu Mikołaja Kopernika.

Hernández-Almeida I., Grosjean M., Tylmann W., Bonk A., 2014, Chrysophyte cyst-inferred variability of warm season lake water chemistry and climate in northern Poland: training set and downcore reconstruction, Journal of Paleolimnology, 53, s. 123-138. https://doi.org/10.1007/ s10933-014-9812-4.

Kaiser K., Hilgers A., Schlaak N., Jankowski M., Kuhn P., Bussemer S., Przegietka K., 2009, Palaeopedological marker horizons in northern central Europe: characteristics of Lateglacial Usselo and Finow soils, Boreas, 38, s. 591-609. https://doi.org/10.1111/j.1502-3885.2008.00076.x.

Kinder M., Tylmann W., Rzeszewski M., Zolitschka B., 2020, Varves and mass-movement deposits record distinctly different sedimentation dynamics since the late glacial (Lake Szurpiły, northeastern Poland), Quarternary Research, 93, 1, s. 299-313. https://doi.org/10.1017/qua.2019.61. 
Kondracki J., 1994, Geografia Polski. Mezoregiony fizycznogeograficzne, Państwowe Wydawnictwo Naukowe, Warszawa.

Kozarski S., 1975, Oriented kettle-holes on outwash planes, Quaestiones Geographicae, 2, s. 99-112. Kozarski S., 1995, Deglacjacja północno-zachodniej Polski: warunki środowiska i transformacja geosystemu ( 20 KA - 10 KA BP), Dokumentacja Geograficzna, 1, IGiPZ PAN, Continuo, Wrocław.

Lamentowicz M., 2006, Zmiany środowiskowe torfowiska Żabieniec - analiza ameb skorupkowych, [w:] Przewodnik terenowy, II Sympozjum Archeologiczno-Środowiskowe „Środowiskowe uwarunkowania osadnictwa", 27-29.09.2006, Uniwersytet Łódzki, Łódź.

Latałowa M., Borówka R.K., 2006, The Allerød/Younger Dryas transition in Wolin Island, northwest Poland, as reflected by pollen, macrofossils, and chemical content of an organic layer separating two aeolian series, Vegetation History and Archaeobotany, 15, s. 321-331. https://doi. org/10.1007/s00334-006-0062-x.

Magny M., 2004, Holocene climate variability as reflected by mid-European lake-level fluctuations and its probable impact on prehistoric human settlements, Quaternary international, 113, 1, s. 65-79. https://doi.org/10.1016/S1040-6182 (03)00080-6.

Mangerud J., Andersen S.T., Berglund B.E., Donner J.J., 1974, Quaternary stratigraphy of Norden, a proposal for terminology and classification, Boreas, 3, s. 109-126. https://doi. org/10.1111/j.1502-3885.1974.tb00669.x.

Marks L., 2002, Last Glacial Maximum in Poland, Quaternary Science Reviews, 21, s. 103-110. https://doi.org/10.1016/S0277-3791 (01)00086-5.

Miotk-Szpiganowicz G., 1992, The history of the vegetation of Bory Tucholskie and the role of man in the light of palynological investigations, Acta Palaeobotanica, 32, s. 39-122.

Ott F., Wulf S., Serb J., Słowiński M., Obremska M., Tjallingii R., Błaszkiewicz M., Brauer A., 2016, Constraining the time span between the Early Holocene Hässeldalen and Askja-S Tephras through varve counting in the Lake Czechowskie sediment record, Poland, Journal of Quaternary Science, 31, 2, s. 103-113. https://doi.org/10.1002/jqs.2844.

Reimer P.J. i inni, 2009, IntCal09 and Marine09 radiocarbon age calibration curves, 0-50,000 years cal BP, Radiocarbon, 51, 4, s. 1111-1150. https://doi.org/10.1017/\$0033822200034202.

Reimer P.J. i inni, 2013, IntCal13 and Marine13 Radiocarbon Age Calibration Curves 0-50,000 Years cal BP, Radiocarbon, 55, 4, s. 1869-1887. https://doi.org/10.2458/azu_js_rc.55.16947.

Ralska-Jasiewiczowa M., 1998, Lake Gościq̨ż, Central Poland: A Monographic Study, Instytut Botaniki PAN, Kraków.

Skulmowska S., 2007, Analiza okrzemkowa osadów dennych jeziora Jelonek w Borach Tucholskich, Pracowania Modelowania Procesów Ekologicznych, Uniwersytet Mikołaja Kopernika, Toruń.

Słowiński M., Błaszkiewicz M., Brauer A., Noryśkiewicz B., Ott F., Tyszkowski S., 2014, The role of melting dead ice on landscape transformation in the early Holocene in Tuchola Pinewoods, North Poland. Quaternary International, 388, s. 64-75. https://doi.org/10.1016/j.quaint.2014.06.018. Starkel L., 1977, Paleogeografia holocenu, Państwowe Wydawnictwo Naukowe, Warszawa.

Tylmann W., Enters D., Kinder M., Moska P., Ohlendorf Ch., Poręba G., Zolitschka B., 2013, Multiple dating of varved sediments from Lake Łazduny, northern Poland: toward an improved chronology for the last 150 years, Quaternary Geochronology, 15, s. 98-107. https://doi.org/10.1016/j. quageo.2012.10.001.

Väliranta M., Kultti S., Seppä, H., 2006, Vegetation dynamics during the Younger Dryas-Holocene transition in the extreme northern taiga zone, northeastern European Russia, Boreas, 35, s. 202-212. https://doi.org/10.1111/j.1502-3885.2006.tb01150.x. 
Walanus A., Nalepka D., 2010, Calibration of Mangerud's boundaries, Radiocarbon, 52, 4, s. 1639-1644. https://doi.org/10.1017/S0033822200056368.

Wulf S. i inni, 2016, Holocene tephrostratigraphy of varved sediment records from Lakes Tiefer See (NE Germany) and Czechowskie (N Poland), Quaternary Science Reviews, 132, s. 1-14. https:// doi.org/10.1016/j.quascirev.2015.11.007.

Zawisza E., 2008, Zapis holoceńskich zmian ekologicznych i klimatycznych w składzie zespołów Cladocera w osadach jezior północnej Polski, Instytut Nauk Geologicznych PAN, Warszawa.

Zawisza E., Filbrandt-Czaja A., Correa-Metrio A., 2016, Subfossil Cladocera and pollen as indicators of natural and anthropogenic trophic changes of Lake Jelonek (Tuchola Forest, N Poland) during the Holocene, Advances in Oceanography and Limnology, 7, 2. https://doi.org/10.4081/ aiol.2016.6234.

\section{Summary}

This paper presents the matter of the environmental reconstruction of laminated lacustrine sediments from the Younger Dryas through to the present day, in particular in respect of microlithofacial analysis and sedimentation rate.

Lake Jelonek is located within the Tuchola Pine Forest of northern Poland (at 53 $45^{\prime} 58 \mathrm{~N}$, $18^{\circ} 23^{\prime} 30$ E). It occupies a subglacial channel immediately adjacent to the Wda Valley. The lake covers 19.9 ha and has a maximum depth of $13.8 \mathrm{~m}$. In 2014, overlapping sediment cores JEL14 (14.23 m) were collected from that deepest part, in order for a full sediment profile including the younger Dryas and the Holocene to be created. Most of the sediment is found to be laminated.

Sedimentation rate was reconstructed for the lake, along with microlithofacial variability of different sections of the sediment. The results obtained were related to an age depth model based on 14 AMS radiocarbon dates, varve chronology and the Askja AD 1875 cryptotephra; and was correlated with pollen profiles.

The Holocene sediment record of Lake Jelonek exhibits differences between low and high sedimentation rate intervals and varved and non-varved intervals. From the beginning of the Holocene through to the Subatlantic period, sedimentation proved to be a stable phenomenon. However, in the Subatlantic period, the average sedimentation rate increased to $7.7 \mathrm{~mm}$ per year from $2.2 \mathrm{~mm}$, with maximum rates even reaching $15.3 \mathrm{~mm} /$ year. This period is reflected in a lack of lamination and the appearance of redeposited deposits. These changes prove particularly sensitive to local impact, with distinct alternations of low and high sedimentation rates and varved and non-varved intervals.

The most probable drivers for the observed variability reflect a combination of changes of climate plus anthropogenic deforestation during periods of settlement that enhanced the sensitivity of the lake to wind stress. A summary of all analyses allowed for the identification of periods of rapid change in sedimentation, and - indirectly - for the reproduction of changes in the water level and anthropopressure in and around Lake Jelonek. Such results contribute to a better understanding of local influences on fluctuations in lake sedimentation processes characteristic for the north of Poland, but also Central Europe more widely. 